\title{
Utilization of Compost: Use and Economical Value of Compost
}

\author{
Ahmet Merhabi
}

\author{
Faculty of Agriculture, Ferdowsi University of Mashhad, Iran
}

\begin{abstract}
The paper talked about use and economical value of compots which is use the Wind Row system is the simplest and least expensive composting process. Compost raw materials are stacked lengthwise. Nutrient content Good compost contains macro nutrients> 1.5\% Nitrogen, P2O5 (Phosphate)> 1\% and K20 (Potassium)> 1.5\%, in addition to other micro elements. C / $\mathrm{N}$ ratio between $15-20$, above or below is not goodThe result defined that organic waste can be processed using simple technology and the processed products can be used directly as natural fertilizers.
\end{abstract}

Keywords: Compost Raw, Organic Waste, Natural Fertilizers

\section{Introduction}

Waste or waste (refuse) is a part of something that is not used, disliked or something that must be disposed of, which generally comes from activities carried out by humans (including industrial activities), but not biological (because human waste is not included in it) and generally solid. Sources of waste can vary, including: from households, markets, shops, offices, public buildings, industries, and roads. Waste decomposition with the help of bacteria is obtained by compost or humus. Anaerobic decomposition is slow and odorous, but aerobic decomposition is relatively fast from anaerobic decomposition and less odorous.

\section{Understanding Compost}

Agnes \& Lewnard (2003) research defined that compost is the result of changes to organic matter by microbes, with the final result being compost which has a low $\mathrm{C} / \mathrm{N}$ ratio. The ideal material for composting has a $\mathrm{C} / \mathrm{N}$ ratio of about 30 , while the resulting compost has a $\mathrm{C} / \mathrm{N}$ ratio $<20$. Organic material which has a $\mathrm{C} / \mathrm{N}$ ratio much higher than 30 will be dissolved over a long time, on the contrary if the ratio is too low there will be loss of $\mathrm{N}$ due to evaporating during the renovation process. Compost produced by fermentation using effective microbial technology is known as bokashi. In this way the composting process can be shorter than conventional methods.

Basically, composting is an effort to activate microbial activities in order to accelerate the decomposition process of organic matter. What is meant by microbes here are bacteria, fungi and other microorganisms. The organic material here is the raw material for compost, namely straw, municipal waste, agricultural waste, animal / livestock manure and so on. The method of composting varies depending on the conditions of the place of manufacture, the culture of the people, the quality desired, the amount of compost required, the kinds of materials available and the tastes of the maker. It should be noted in the composting process is the moisture in the compost pile. Microbial activity and life are strongly influenced by adequate humidity, not too dry or wet or stagnant (Bess V.H, 2000). 


\section{Nutrient content}

Good compost contains macro nutrients> 1.5\% Nitrogen, P2O5 (Phosphate)> 1\% and K20 (Potassium) $>1.5 \%$, in addition to other micro elements. C / $\mathrm{N}$ ratio between $15-20$, above or below is not good. For business purposes, the compost produced must have a stable quality and a sustainable supply (1) Types of Compost (2) Pure Compost. This fertilizer is intended for organic crop land, but can also be used for non-organic agricultural land. (3) Compost plus microbes ( $N$ binder and $P$ release). This enriched fertilizer is also intended for organic farming, but can also be used for (ordinary) non-organic agricultural land. (4) Compost plus artificial fertilizers. This fertilizer can only be used for non-organic agricultural land ( Cambardella et.al., 2003)

\section{Composting Steps}

The raw materials used should be organic materials that have a high $\mathrm{C}$ and $\mathrm{N}$ ratio (more than 30: 1). Some of them are sawdust, rice husks and goat manure. The time needed to make compost by anaerobic method can be 10-80 days, depending on the effectiveness of the decomposer and the raw materials used. The optimal temperature during the composting process ranges from $35-450 \mathrm{C}$ with a humidity level of $30-40 \%$. The following are the steps for making compost using an anaerobic process. (1) Prepare organic material to be composted. It's best to choose soft materials consisting of plant or animal waste. Materials that can be used include plant forage, tofu dregs, household organic waste, chicken manure, goat manure, etc. Chop the material until smooth, the finer the better. (2) Prepare a Microorganime Effective Decomposer (EM4) as a starter. To do this, mix 1 cc of EM4 with 1 liter of water and 1 gram of sugar. Then let stand for 24 hours. (3) Take the plastic tarp as a base, store the finely chopped organic material on the tarpaulin. Mix the sawdust in the material to increase the ratio of $\mathrm{C}$ and $\mathrm{N}$. Then spray the diluted EM4 solution. Stir until evenly distributed, keep humidity in the range of $30-40 \%$, if it is less humid, you can spray it with water. (4) Prepare an airtight plastic barrel. Enter the organic ingredients that have been mixed earlier. Then cover tightly and let stand for 3-4 days to undergo the fermentation process. The composting temperature during fermentation will range from 35-45o. (5) After four days, check the compost for maturity. Ripe compost is characterized by a fragrant smell like the smell of tape (Chalk et.al., 2013)

Characteristics of good and finished compost: (1) The color of compost is usually dark brown

(2) Good compost does not emit a pungent aroma, but produces a weak odor such as the smell of soil or forest humus. When held and clenched, the compost will clump. When pressed lightly, the lump of compost will crumble easily. Storage of Compost: When compost is ready, it should be stored for 1 or 2 months to reduce toxic elements, although this storage will cause a slight loss of necessary elements such as nitrogen. But in general compost that is stored first is better. Storage of compost must be done with care, especially those that must be maintained are: (1) Keep the humidity less than <20 percent of its weight, (2) Do not expose it to direct sunlight (closed) (3) Take care not to get water / rain directly (closed).

If it is to be packaged, choose packaging materials that are airtight and not easily damaged. The packaging material is impermeable to sunlight better. Compost is a material which, when changed, cannot return to its original state (irreversible). When the compost dries up, the nutrients contained in it will be lost along with the water and when the compost is added with water again, the nutrients that were lost cannot be returned. 


\section{Compost Making Method}

\section{Wind Row System}

According to Ackelkamp et.al (2013) the Wind Row system is the simplest and least expensive composting process. Compost raw materials are stacked lengthwise, pile height 0.6 to 1 meter, width 2-5 meters. Meanwhile, the length can reach 40-50 meters. This system utilizes natural air circulation. Optimization of the width, height and length of the pile is greatly influenced by the condition of the raw material, the gaps, pore space, and air circulation to reach the center of the raw material pile. Ideally, the pile of raw materials must be able to release heat, to compensate for the heat loss generated as a result of the decomposition of organic matter by microbes. This windrow system is a good composting system that has been successfully carried out in many places to process manure, garden waste, sewage sludge, municipal waste and others. To regulate temperature, humidity and oxygen, in this windrow system, a periodic reversal process is carried out. This is the principle that differentiates it from other composting systems. The weakness of this Windrow system is that it requires a fairly large area of land.

\section{Aerated Static Pile System}

Another more advanced composting system is the Aerated Static Pile. In principle, the composting process is almost the same, with a windrow system, but in this system a perforated pipe is installed to drain the air. Air is pressed using a blower. Because there is air circulation, the pile of raw materials being processed can be higher than 1 meter. The process itself is regulated by oxygen delivery. If the temperature is too high, the oxygen flow is stopped, while when the temperature drops the oxygen flow is increased. Because there is no reversal process, the compost raw material must be made homogeneous from the start. In mixing there must be sufficient air space. Raw materials that are too big and long must be cut into pieces $4-10 \mathrm{~cm}$ in size.

\section{In Vessel System}

The third system is the in vessel composting system. In this system can use any kind of container, it can be silo or longitudinal trench. Since this system is limited by the container structure, it is a good one to use to reduce the effects of unpleasant odors such as the smell of municipal waste. The in vessel system also uses the same air regulation as the Aerated Static Pile system. This system has separate compost intake and finished compost dispensing doors.

\section{Uses and Benefits and Economic Value of Compost \\ Uses of Compost}

Basically compost can increase the chemical and physical fertility of the soil which in turn will increase crop production. In horticultural crops (fruits, ornamental plants, and vegetables) or perishable plants, it is almost impossible to grow without compost. Likewise in the plantation sector, the use of compost has been shown to increase crop production. Compost makes fruits and vegetables taste better, more fragrant and more massive. This is what encourages the development of organic plants, apart from being healthier and safer because they do not use chemical pesticides and fertilizers, they taste better, are more brittle, and smell good. Organic waste will naturally undergo decomposition by various types of microbes, animals that live in the soil, enzymes and fungi. This decomposition process requires certain 
conditions, namely temperature, air and humidity. The more suitable the conditions are, the faster the compost will be formed, in 4-6 weeks it will be ready. If organic waste is piled up, it will take months for it to become compost. In the composting process, heat will arise due to microbial activity. This is a sign that the microbes chew the organic material and turn it into compost. The optimal temperature for composting that must be maintained is $45^{\circ} \mathrm{C}-65^{\circ} \mathrm{C}$. If it is too hot, it should be inverted, at least every 7 days. Benefits of Compost: (a) Increase soil fertility (b) Improve soil structure and characteristics, (c) Increase soil water absorption capacity, (d) Increase soil microbial activity, (e) Improve crop quality (taste, nutritional value, and quantity harvest) (f) Provide hormones and vitamins for plants (g) Suppress the growth / attack of plant diseases. (h) Increase nutrient retention / availability in the soil (Agnew et al., 2003).

\section{Economic Value of Compost}

Composting can reduce the amount of waste so that it will reduce the operational costs of destroying waste. The final garbage collection bin can be used for a longer time, as less waste is collected. Thus, it will reduce the investment in TPA land. Compost can improve soil conditions and is needed by plants. This means that compost has a competitive and economic value, which means that compost can be sold. The use of inorganic fertilizers can be suppressed so as to increase the efficiency of their use.

\section{Standardization of Compost Making}

By knowing that the quality of compost is strongly influenced by the processing process, while the compost processing process itself is strongly influenced by humidity and the ratio of $\mathrm{C}$ and $\mathrm{N}$ raw materials, so to determine compost standardization is to standardize the compost-making process and standardize compost raw materials, so that compost is obtained. have certain standards. After the standard compost raw material mixture can be met, namely the ideal humidity of 50-60 percent and has a $\mathrm{C} / \mathrm{N}$ ratio of 30: 1 raw materials, there are still other things that must be considered during the composting process, namely monitoring of temperature, humidity., odor or aroma, and pH (Eckelkamp et al., 2016).

\section{Temperature Observation}

Heat is generated as a byproduct of the process carried out by microbes to break down organic matter. This temperature can be used to measure how well the composting system is working, besides, it can also be seen how far the decomposition has progressed. If the compost rises to a temperature of $40^{\circ} \mathrm{C}-50^{\circ} \mathrm{C}$, it can be concluded that the compost raw material mixture contains enough Nitrogen and Carbon and enough water (sufficient moisture) to support the growth of microorganisms. Temperature monitoring should be carried out using a temperature tester which reaches deep into the compost pile (Hadar, 2011)

\section{Moisture Observation}

Making compost will run well in a mixture of compost raw materials that have moisture content between 40 - 60 percent of the weight. At a lower water vapor level, the activity of microorganisms will be inhibited or completely stopped. At higher humidity levels, the process is likely to be anerobic, resulting in a foul odor. When compost is selected for mixing, the moisture content can be measured or estimated. After the composting process takes place, moisture measurement does not need to be repeated, but it can be observed immediately the adequacy of the moisture content. If the compost-making process is in 
progress, then a foul smell appears, it is certain that the compost contains excessive moisture content. This excess water vapor has filled the pore spaces, thus blocking the diffusion of oxygen through the compost materials. This is what makes things anaerobic.

\section{Odor / Aroma Observation}

Stated by Haug (2018) if the composting process is running normally, it should not produce a strong odor (foul smell). However, in making compost it will not be completely free from odors. By utilizing the sense of smell, it can be used as a tool to detect problems that occur during the composting process. If you smell ammonia, you should suspect that the compost mixture contains excess nitrogen (too low $\mathrm{C} / \mathrm{N}$ ratio). If you smell bad, the compost mixture may contain too much water. If this happens, do a reversal (in the windrow system), add oxygen to the Aerated Static Pile or In Vessel system.

\section{Observation $\mathrm{Ph}$}

Observation of compost $\mathrm{pH}$ serves as an indicator of the compost decomposition process. Compost microbes will work at a neutral $\mathrm{pH}$ to slightly acidic, with a $\mathrm{pH}$ range between 5.5 to 8. During the early stages of the decomposition process, organic acids will be formed. This acidic condition will encourage fungal growth and will decompose lignin and cellulose in the compost material (Scheuerell \& Mahaffee, 2002). During the composting process, these organic acids will become neutral and the compost ripe usually reaches a $\mathrm{pH}$ between 6 - 8 . If anaerobic conditions develop during the composting process, organic acids will accumulate.

\section{Advantages and Disadvantages of Compost}

\section{Excellence}

Organic fertilizers contain complete nutrients, both macro and micro nutrients. This condition is not owned by artificial fertilizers (inorganic). Organic fertilizers contain organic acids, including humic acid, fulfic acid, hormones and enzymes that are not present in artificial fertilizers which are very useful for both plants and the environment and microorganisms. Organic fertilizers contain soil macro and micro-organisms which have a very good effect on the improvement of soil physical properties and especially soil biological properties. (1) Improving and maintaining soil structure (2) Being a buffer for soil pH (3) Supporting the inorganic nutrients given, (4) Helping to maintain soil moisture (5) Safe to use in large quantities and in excess even (6) Does not damage the environment (Scheuerell, 2003).

\section{Deficiency}

Based on Scheurell et. Al (2002) the amount of nutrient content is small, so the amount of fertilizer applied must be relatively large when compared to inorganic fertilizers. Because of their large number, they require additional operational costs for transportation and implementation. In the short term, especially for soil - soil that is already poor in nutrients, the application of organic fertilizers which requires a large amount of it becomes a cost burden for farmers. Meanwhile, the reaction or response of plants to the application of organic fertilizers is not spectacular with artificial fertilizers.

\section{Conclusion}

Compost is the remains of living things that have undergone weathering, their shape has changed like soil and is odorless. Compost has physical and chemical properties similar to soil. 
However, it contains nutrients that are very beneficial for plants. Organic waste can be processed using simple technology and the processed products can be used directly as natural fertilizers. Processing waste garbage (organic) biologically and takes place in an aerobic and anaerobic atmosphere.

\section{References}

Agnew, J. M., \& Leonard, J. J. (2003). The physical properties of compost. Compost Science \& Utilization, 11(3), 238-264.

Bess, V. H. (2000). Understanding compost tea. BioCycle, 41(10), 71-71.

Cambardella, C. A., Richard, T. L., \& Russell, A. (2003). Compost mineralization in soil as a function of composting process conditions. European Journal of Soil Biology, 39(3), 117-127.

Chalk, P. M., Magalhães, A. M., \& Inácio, C. T. (2013). Towards an understanding of the dynamics of compost $\mathrm{N}$ in the soil-plant-atmosphere system using $15 \mathrm{~N}$ tracer. Plant and Soil, 362(1-2), 373-388.

Eckelkamp, E. A., Taraba, J. L., Akers, K. A., Harmon, R. J., \& Bewley, J. M. (2016). Understanding compost bedded pack barns: Interactions among environmental factors, bedding characteristics, and udder health. Livestock Science, 190, 35-42.

Hadar, Y. (2011). Suppressive compost: when plant pathology met microbial ecology. Phytoparasitica, 39(4), 311-314.

Haug, R. (2018). The practical handbook of compost engineering. Routledge.

Scheuerell, S. (2003). Understanding how compost tea can control disease. BioCycle, 44(2), 20-20.

Scheuerell, S., \& Mahaffee, W. (2002). Compost tea: principles and prospects for plant disease control. Compost Science \& Utilization, 10(4), 313-338. 